\title{
Business as a Calling? Some Ethical and Spiritual Ramifications of Wealth and Power
}

\author{
Roman Míčka
}

The subtitle "Some Ethical and Spiritual Ramifications of Wealth and Power" may well be too broad and liberal, it is obviously impossible to encompass the whole breadth of the thus conceived topic here, nor to attempt an easy synthesis of biblical, theological, ethical, political and economic aspects. From the biblical point of view the attitude to wealth can be simplified to a quest for some tension between the parable "Of the camel and the needle-eye" (Mt 19:23-26), a frequent spiritual argument against wealth owned by a Christian, through the parable " Of workers in the vineyard" (Mt 20:1-16) receiving "in the socialist manner" the same pay regardless of the amount of work done, to the parable "Of talents" (Mt 25:14-30), where the servants are evaluated by hard capitalist criteria exclusively with a utilitarian respect to the ability to valorize the entrusted property, with no mention of any ethical considerations. The message of the above parables cannot be primarily conceived as focusing on the sphere of economic relationships, but as expressions of certain spiritual aspects of the Kingdom proclaimed by Jesus. Nonetheless, from what the first parable says we can humbly assume that the rich will be judged charitably, with regard to the responsibility and burden entrusted to them, and also with regard to what we can learn from the last parable mentioned, that the extra they receive is that which is taken away from those less apt and capable. For to the terror raised among the disciples by the image of the camel passing through a needle-eye Christ reacts with reference to salvation as follows: "With man this is impossible, but with God all things are possible". The tension among these parables is also expressed by the tension between the ways in which a Christian is called to public life and economic activity.' Some are called to poverty and to a life of service to others, often financially dependent on the benevolence of the rich or today rather on the organizational power of the state, others can be called to responsibility for generating and managing wealth, which is a necessary attribute of the common good and the potential of solidarity, whether voluntary or involuntary.

Christianity sides with the poor, it is to a great extent a preferential option for the poor, it admonishes against dependency not only on property, but on all earthly realities. No one can serve two masters - "You cannot serve God and money" (Mt 6:24). In some cases and for someone who cannot pass this difficult test, Christ recommends getting rid of property altogether, but the challenge "go, sell what you possess and give to the poor" (Mt 19:21) is in Christian ethical tradition generally not considered universal, but rather addressed merely to that Rich Young Man. From the point of view of Christianity, relationship to property, analogically to other spheres of human life, ought to be reserved and must not replace or displace relationship to God; a human must be free of earthly realities, not dependent on them. A frequently cited analogy is Christ's call to hate one's father, mother, wife and children for Christ (cf. Lk 14:26), which is not intended to mean a repudiation of relatives, but an appeal to an appropriate hierarchy of values. With direct reference to property we can even find a statement warning against the attraction of wealth: "For the love of money is a root of all kinds 
of evils. It is through this craving that some have wandered away from the faith and pierced themselves with many pangs. But as for you, O man of God, flee these things. Pursue righteousness, godliness, faith, love, steadfastness, gentleness." (1 Tim 6:10-11).

Of course, from the social point of view Christianity is first of all an "option for the poor", Jesus sides with the poor and calls to liberation from the bonds of dependency on property. However, as an option for the poor it should not automatically become an "option against the rich", it should not primarily legitimize dispossession of property and its involuntary redistribution, as sometimes happens even in the intentions of certain forms of Christian-oriented social ethics. In connection with the topic "pastoral care of the rich" our purpose is, first, to point out how problematic the ambivalent, often even malevolent attitude to the rich and powerful of this world is and, second, to use some outstanding incentives of the famous book Business as a Calling. Work and the Examined Life $(1996)^{2}$ by Michael Novak, where the author attempts a spiritual vindication of business.

\section{When wealth increases, so do sponges}

Responsible management and generation of property is an important contribution to the common good. Modern capitalism, whose advocates underline the enormous dynamics of gradual eradication of poverty clearly apparent in every further generation, is subject to ambivalent evaluations. For example, Peter Berger in his book The Capitalist Revolution: Fifty Propositions about Prosperity, Equality, and Liberty (orig. 1986) says that capitalism "...set free the greatest productive power in human history. No other socio-economic system has yet been able to generate a comparable productive power". ${ }^{3}$ An advocate of capitalism, the Catholic theologian Michael Novak adds majestically: "After five thousand years of groping people finally found a way of obtaining wealth by means of a permanent systematic process". "When expelled from the Garden of Eden, Adam faced a world that let humans suffer and starve for centuries. Today the mystery of permanent material progress has been resolved. The responsibility for elevating suffering and hunger is no longer God's, but ours" ${ }^{5}$ Both authors suggest that pre-capitalist history did not favor eradication of poverty and generation of decent material life conditions for humans. Crucial in this expansive rise of wealth are - who else but capitalists - entrepreneurs, who usually did not come from old pre-modern rich aristocratic elites, but rather from the lower middle class of townspeople. These people did not invent the long-respected principle of private property, neither did they invent age-old trade and commerce, they were not the first to accumulate profit. Nor did they invent covetousness and greed, considered by some to be an innovation accompanying the rise of capitalism - this sin has been with humanity since its origins. For capitalism originates in the human aptitude to invent and innovate - in human capacity to create. As the very word "capitalism" suggests, it is a system of institutions whose goal is to liberate human creative powers and make use of the virtue of practical reason. Capitalism is founded on reason - on appropriate use of human reason - the head - "caput". Thus on this interpretation the word "capitalism" does not primarily refer to money, but to the "human capital" - knowledge, invention, know-how, initiative, enterprise, capacity to organize, ability to co-operate. Capitalism is accompanied by a certain ethos, which according to Max Weber

2 Michael NOVAK, Business as a Calling. Work and the Examined Life, New York: The Free Press, 1996.

3 Peter L. BERGER, Kapitalistická revoluce: padesát propozic o prosperitě, rovnosti a svobodě, Bratislava: Archa, 1993, p. 61-62.

4 Michael NOVAK, Duch demokratického kapitalismu, Praha: Občanský institut, 1992, p. 17.

5 Ibid., p. 28. 
derives from Calvinist anxious religious neurosis, while Novak believes that the core of capitalism is precisely creativity. Novak considers creativity to be the central point of Catholic, not Protestant ethics, which he attempts to defend in his book The Catholic Ethic and the Spirit of Capitalism (1993). ${ }^{6}$

However, despite their obvious contribution to society, the new elites - the contemporary rich - the capitalists are not held in great esteem. The typical contemporary perception of the rich and powerful is that of bandits and parasites of the society, rather than major contributors to it and co-creators of the common good. A true basis and partial justification of this altogether distorted view may consist in the often overlooked aspect of distinguishing between ways of obtaining property in the sense of certain legitimacy. Many entrepreneurs who have become markedly rich indeed founded their enterprise on a creative contribution in a certain sphere of human activity and thus contributed to social development. On the other hand there is a fairly broad section of business activities of non-creative character, i.e., those participating in corrupt co-operation with the state and public institutions. This aspect, rarely mentioned and distinguished, is underlined e.g. by the economist Pavel Kohout in his article Why the economy is in doldrums, ${ }^{7}$ where - based on the work of the economists James Robinson and Daron Acemoglu ${ }^{8}$ - he among other things distinguishes between creative and extractive elites. Creative elites became rich in virtue of their intelligence, creativity, and diligence, extractive elites become rich by suspicious privatizations, manipulated state commissions, subsidies, and holes in laws. Evidently, liberal economists such as Novak will - with respect to the creative dimension of capitalism they emphasize - not favor non-creative forms of accumulating property, in which an important part is often played by the state and corruption in its institutions, not free, competitive market environment. A strong state, large amounts of public property and public money (privatizations, public commissions, Euro-subsidies, ecological subsidies, etc.) often help the rise of "extractive elites" to the detriment of creative ones.

Regardless of the character of business activities, with the rise of state power in $20^{\text {th }}$ century, especially in its second half, states often took rich economic elites as hostages of their social experiments and an important source of income. In some countries, e.g. in pre-Thatcher Britain, progressive tax rate was $83 \%$, but the effective limit of taxation was up to the unbelievable $95 \%$, in pre-Reagan USA the highest rate of income tax was 70\%. There followed a more favorable tax era, but at present, when in times of crisis and situation of dynamic globalization the nonsustainability of the current level of public expenditure, claims and social conveniences of the rampant welfare state is becoming evident, politicians are again asking whom and how they could tax more radically and gain popularity with the electorate into the bargain. A vivid example is the proposal of a 75\% "tax of the rich" by the French president François Holland. In this context one cannot but recall a quotation from the Old Testament, from the book Qohelet: "When goods increase, they increase who eat them, and what advantage has their owner but to see them with his eyes?" (Eccl 5:10).

"Rich Americans should pay higher taxes", 9 said Obama in his first speech after elections, in a situation when $10 \%$ of Americans with the highest income are paying an income tax of $45.1 \%$ and at the same time almost a half $(47 \%)$ of Americans are paying no income tax at all. In this

6 Cf. Michael NOVAK, The Catholic Ethic and the Spirit of Capitalism, New York: The Free Press, 1993.

7 Cf. Pavel KOHOUT, Proč ekonomika stagnuje (on-line), online at http://www.novaustava.cz/clanky/proc-ekonomika-stagnuje, accessed 19 August 2013.

8 Cf. Daron ACEMOGLU, James ROBINSON, Why Nations Fail: The Origins of Power, Prosperity, and Poverty, New York: Crown Publishers, 2012.

9 Cf. Bohatí Američané by měli platit vyšší daně, prohlásil v prvním povolebním projevu Obama, online at http://www.rozhlas.cz/zpravy/ amerika/_zprava/bohati-americane-by-meli-platit-vyssi-dane-prohlasil-v-prvnim-povolebnim-projevu-obama--1135177, accessed 3 July 2013. 
context one must legitimately ask what are the limits of legitimate taxation and redistribution of wealth to all, especially from those whose incomes (and thus also abilities, initiative and creativity) are considered to be common property that the state and other citizens can claim at any time. Extensive expectations of the potential to solve social problems by means of dispossessing and redistributing property or by arousing "class hatred" was addressed already by the first social encyclical while criticizing socialist ideals: "To remedy these wrongs the socialists, working on the poor man's envy of the rich, are striving to do away with private property, and contend that individual possessions should become the common property of all, to be administered by the State or by municipal bodies. (...)But their contentions are so clearly powerless to end the controversy that were they carried into effect the working man himself would be among the first to suffer. They are, moreover, emphatically unjust, for they would rob the lawful possessor, distort the functions of the State, and create utter confusion in the community". ${ }^{10}$ It is somewhat paradoxical that the rich who had gained their property by other activity than business enterprise (artists, athletes, etc.) are not under such strong pressure from society and their wealth is not subjected to such strong moralizing questioning.

\section{Novak's book Business as a Calling}

And now let us discuss Novak's book Business as a Calling - Work and the Examined Life (1996), where the author attempts to partially spiritually vindicate the world of business and businessmen themselves and address the Christian dimension of a vocation in business. As a theologian Novak first reflects on the strong anti-capitalist tradition within Christianity - the constant antagonism of many currents of Christian thought as well as representatives of the hierarchy is according to him deeply related to the strong "anti-capitalist tradition", rooted in eras when the Church was financially dependent on old pre-modern elites, aristocracy of feudal character. A further cause of resistance to the world of enterprise and business are according to Novak intellectuals, whose education was connected with the aristocratic tradition of the liberal arts and social sciences. ${ }^{11}$ Since the very origin and beginning of development of capitalist economy in $19^{\text {th }}$ century the intellectuals of the whole world have been parading against the free market. "Intellectuals have rejoiced ever since in defining the business class as their number one class enemy, the epitome and cause of social evil."12 According to Novak intellectuals have become used to identifying themselves with aristocracy, they are "noblemen of the spirit" who have contempt for the vulgar stratum of "petty bourgeois" and the new rich pursuing a "bourgeois" non-aristocratic morality and reject the low and materialistic world of business. This is reflected in the way business elites are represented in film - up to 1960s an American businessman was commonly represented as a positive figure in Hollywood films, since 1970s and 1980s mostly as a villain, ruffian and thief. ${ }^{13}$ A further reason for resentment against capitalism and capitalists Novak identifies is plain envy, which he considers to be one of the most destructive forces in society and which manifests itself by constant emphasis on progress towards material equality. ${ }^{14}$

Novak broadly points out the sorrowful, unappreciated and difficult lot of persons active in the world of business. There are many biases and myths concerning the business sphere and engagement in it, as well as the capitalist economic system as a whole. Persons active in the

\footnotetext{
10 Rerum novarum, art. 3.

11 Cf. Michael NOVAK, Business as a Calling, p. 5.

12 Ibid., p. 55.

13 Cf. ibid., pp. 7-10.

14 Cf. ibid., pp. 90-92.
} 
world of business, especially the more successful and wealthy ones, are perceived as morally suspicious, striving merely for profit. In the eyes of many, business activity is of little spiritual value, the distorted media image evokes the impression that this activity is almost inseparably tied to character traits such as covetousness, greed, vulgarity, dishonesty. While Novak does not entertain illusions concerning the reality and practice current in the world of business, he does not consider the system and persons involved in it to be necessarily immoral and evil. He strives to vindicate the morality of business enterprise and he even considers engagement in the economic sphere to be a "vocation" in the religious sense. "A career in business is not only a morally serious vocation but a morally noble one. Those who are called to it have reason to take pride in it and to rejoice in it." ${ }^{15} \mathrm{He}$ also points out that according to sociological surveys in the USA individuals active in the world of business even rank among persons with the highest level of religiosity, along with soldiers and athletes. ${ }^{16}$ That might be because in these professions the factor of success is linked with great risks and contingent factors operating beyond the sphere of the individual's control.

According to Novak generation of wealth is not morally neutral. It is rather an a priori morally right way of fulfilling personal responsibility. Business can be conducted in both moral and immoral way, as can other spheres of activity allowing space for human freedom. The capitalist system, just as all other human activity, is affected by human sin. That, however, is not a reason to eliminate it or fundamentally re-organize and regulate it. An inclination to personal economic initiative is an expression of natural freedom and it is necessary to establish a suitable institutional dimension for it. But the cultural and moral dimension of the system of democratic capitalism is in decline and it is necessary to seek its revitalization. Character formation, which used to be the prime function of educational institutions, has receded virtue has been replaced with moral neutrality. According to Novak virtue should become the vital interest of business, even for purely pragmatic reasons - the ethical code of a company is an investment promoting its future prosperity, even if from a short-term point of view economic activity without moral respects might be more successful. In this context Novak even attempts to define the three "cardinal virtues of business" that may supplement the classically defined virtues in the new situation of modern era. He writes that "Business ethics means a great deal more than obeying the civil law and not violating the moral law. It means imagining and creating a new sort of world based on the principles of individual creativity, community, realism, and the other virtues of enterprise. It means respecting the right of the poor to their own personal economic initiative and their own creativity. It means fashioning a culture worthy of free women and free men - to the benefit of the poor and to the greater glory of God." 17

Of the three cardinal virtues of business Novak identifies ${ }^{18}$ he especially underlines creativity, supported by habits such as courage, hard work and endurance. It is the main virtue which starts and maintains the whole system of generating wealth. While in earlier periods the primary factor of wealth was agricultural land and natural resources, at present these factors are of secondary value for developing wealth, even unessential. The main source of wealth has become intellectual capital. ${ }^{19} \mathrm{~A}$ human being as an imago Dei is called to dynamically finish and re-fashion the created world. Another virtue of business is the virtue of building community, supported by habits such as honesty, magnanimity and a sense of justice. Almost all work and creative activity is done for someone else, God gave humans the capacity to generate more

15 Ibid., p. 13.

16 Cf. ibid., pp. 43-45.

17 Ibid., p. 133.

18 Cf. Ibid., pp. 117-133.

19 Cf. Centesimus annus, art. 32. 
in life than they themselves consume. That is a presupposition of economic progress and mutual enrichment. The modern trade system is an expression of the mutual interconnectedness of humanity, as John Chrysostom already suggested ${ }^{20}$. The third virtue of business is according to Novak the virtue of practical realism, supported by habits such as the ability to listen, be attentive and open-minded, the ability to consider wider contexts, be self-critical and willing to admit one's mistakes. It is a virtue closely related to the cardinal virtue of practical wisdom (phronesis).

Novak does not assign great value to the role of the state in creating satisfactory life conditions and work positions. On the other hand, he considers the role of business to be crucial. He says: "Business is, bar none, the best real hope of the poor. And that is one of the noblest callings inherent in business activities: to raise up the poor." 21 While states, especially in the course of several last decades, actively make citizens dependent on their structures, mechanisms of redistribution and subsidy, business can become an arena of freedom and emancipation from the state in developing an independent civil society. As Novak says: "Opportunities and jobs are more valuable to them than handouts from a government that treats them like serfs." ${ }^{22}$ And elsewhere: "The vocation of business is the single most strategic vocation in the work of social justice. It is the vocation most necessary for lifting the poor out of poverty. Business creates jobs where jobs did not exist before." ${ }^{23}$ According to Novak, in a well-organized free democratic society the state should fulfill vital, but very limited functions. In this context he says: "In the project of self-government, business is without doubt the single largest institution of civil society. The moral health of society, therefore, depends to a great extent on the moral character of business leaders." ${ }^{24}$

Novak repeatedly applauds the Pope John Paul II., who took pains to morally vindicate the meaning and purpose of business and businessmen, quoting among others his Address to the Entrepreneurs of Milan delivered in Milan in 1983: "The level of welfare enjoyed by contemporary society would be inconceivable without the dynamic personality of the entrepreneur, whose function it is to organize human work and production means, in order to produce the goods and services necessary for social prosperity and progress." 25

\section{The capitalist - a contemporary hero?}

From the point of view of social justice one must note that wealthy citizens ought to participate proportionately in developing the society and systematically contribute to integral social development. There is, however, the grave question of the limits of solidarity, for which just limits must be set. According to the encyclical Quadragesimo anno (1931), social justice really implies a certain amount of redistribution and elimination of extreme social inequalities: "To each, therefore, must be given his own share of goods, and the distribution of created goods, which, as every discerning person knows, is laboring today under the gravest evils due to the huge disparity between the few exceedingly rich and the unnumbered propertyless, must be effectively called back to and brought into conformity with the norms of the common good, that is, social justice." ${ }^{26}$ The newest social encyclical by Benedict XVI. Caritas in veritate (2009) affirms this attitude: "The market is subject

20 Cf. Michael NOVAK, Business as a Calling, p. 38-39.

21 Ibid., p. 37.

22 Ibid., p. 57

23 Michael NOVAK, The Universal Hunger for Liberty. Why the Clash of Civilizations Is Not Inevitable, New York: Basic Books, 2004 , p. 52.

24 Michael NOVAK, Business as a Calling, p. 53.

25 Michael NOVAK, Katolické sociální myšlení a liberální instituce, Praha: ČKA, 1999, p. 225.

26 Quadragesimo anno, art. 58. 
to the principles of so-called commutative justice, which regulates the relations of giving and receiving between parties to a transaction. But the social doctrine of the Church has unceasingly highlighted the importance of distributive justice and social justice for the market economy, not only because it belongs within a broader social and political context, but also because of the wider network of relations within which it operates." 27

On the other hand, one cannot accept the identification of distributive ideals, as they are presented e.g. by John Rawls - the core of his theory of justice is the statement "Social and economic inequalities are to be arranged so that they are to be of the greatest benefit of the least-advantaged members of society." This may be desirable in a situation fundamentally endangering the dignity and basic rights of a human being by poverty, but not in the context of prosperous societies, which by highly sophisticated redistributive means pursue a deformed ideal of quality of life derived from unjustified claims and social rights. Rawls' theory of justice is a materialist reduction transposing problems of justice, human rights and democracy to the instrumental level of a comprehensive securing of prosperity and equal opportunities by institutional means. ${ }^{28}$ Such conception of justice is a redistributive automaton, knowing no limits or moral correctives asking about the appropriateness of prosperity and consumption, which is completely beyond the scope of the principle of subsidiarity. Solidarity in society cannot consist in constant search for redistributive means of decreasing the differences in society, but precisely in securing the minimal humanly dignified basic conditions with respect to the principle of subsidiarity. Of course, the definition of poverty and undignified conditions of human life partially derive from the relative standards of development of the society in question, but it should never become an instrument of expansive redistribution. Solidarity as one of the essential principles of the social doctrine of the church "(...) ... a firm and persevering determination to commit oneself to the common good; that is to say to the good of all and of each individual, because we are all really responsible for all", ${ }^{29}$ is a crucial aspect of the common good of society. In the context of the developed West, where mechanisms of solidarity have exceeded reasonable limits, we must rather seek its complementary corrective - subsidiarity. Failure to respect this principle, which already the encyclical Quadragesimo anno views as an important principle "which cannot be set aside or changed", results in "... an injustice and at the same time a grave evil and disturbance of right order" ${ }^{30}$ In this context, the encyclical Centesimus annus by John Paul II. criticizes rampant welfare states giving rise to abuse of social systems, loss of moral resources and potential to responsibility, to great increase of state expenditure and thus to disproportionate redistribution from the "rich" to the "poor". 31

To conclude let us recall the famous, now also filmed, novel by the controversial objectivist philosopher of Russian origin Ayn Rand Atlas Shrugged (1957). Let us pass over the problematic, radically individualist, solidarity contesting point of departure, which is not fully consistent with the Christian conception of ethics, and focus on the way she depicts some of her fundamental insights concerning the functioning of free capitalist society. In the novel the rich, capable entrepreneurs, managers, scientists and other creative and intelligent personalities are under such strong pressure from state regulations, limitations and bullying, that they decide to leave the society. Rand considers their creativity, initiative and other exceptional and rare abilities to be the motor of civilization, their "strike" and gradual departure results in the civilization's breakdown and everything essential stops working, while the state itself is

27 Caritas in veritate, art. 35 .

28 Cf. Samuel SCHEFFLER, The Appeal of Political Liberalism, online at http://ebookbrowse.com/scheffler-the-appeal-of-political-

liberalism-pdf-d347933808, accessed 3 July 2013.

29 Sollicitudo rei socialis, art. 38.

30 Quadragesimo anno, art. 79.

31 Cf. Centesimus annus, art. 48. 
unable to compensate for this deficiency and fulfill its essential functions. The image of Atlas carrying on his shoulders the burden of the whole, who under great pressure decides to shrug his shoulders, move back, is impressive and ought to incite us to apprehend the outstanding significance, indispensability of such persons, and to appreciate them morally, also from the point of view of Christian ethics.

These incentives should help us seek respect, admiration, appreciation and broader understanding of the so-called "rich", whom we can of course imprecisely and incompletely identify with the business elites of the present. These are especially the above mentioned "creative elites", who by their diligence, innovation, invention and luck markedly contribute to economic development. These draught horses of the economy, investors, creators of material values and workplaces, often also donors, beneficiaries and contributors, carry a singular burden of responsibility and disproportionate load, which is rarely paid back by social appreciation of their contribution to the common good and certainly not by a greater feeling of happiness. Many of us live off their creativity, initiative and taxes, and to view them as parasites of society is wholly incorrect and improper. In any differentiated evaluation of the morality of wealth and the rich these incentives should be taken into consideration.

\section{Business as a Calling? Some Ethical and Spiritual Ramifications of Wealth and Power}

Abstract This paper deals, in the context of the topic of "pastoral care of the rich", with the problematic nature of the ambivalent attitude to the rich and powerful people of this world. Based on the potent incentives of the book Business as a Calling. Work and the Examined Life (1996) it tries to interpret their difficult position and vindicate the business sphere. The topic is set in the context of some impulses of Catholic Social Doctrine.

Key words Business, Calling, Pastoral Care, Wealth and Power, Taxes, Redistribution, Social Ethics, Catholic Social Doctrine 